JOURNAL OF ENGLISH STUDIES, II (2000), 51-60

\title{
A CHICANO CHILDHOOD EXPERIENCE
}

\author{
AMAIA IBARRARÁN BIGALONDO \\ University of the Basque Country
}

\begin{abstract}
The difficult social and cultural situation that the Chicano community has suffered after the signing of theTreaty of Guadalupe Hidalgo in 1848, has been overtly manifested in the Literature produced by its writers. Themes such as the social and economical conditions of the members of the Chicano community, schooling and housing, the situation of the workers in the fields, portrayals of the first organized political movements, family and domestic relationships etc., are widely found in the Literature written by Chicano authors. Chicanas, on their part, also use the novel for vindicatory purposes. Their body of Literature also deals with subjects that account for their constrained existence as members of an oppressed gender and ethnic group. The first Chicano novels are, in general terms, therefore, "adult" novels even though Monserrat Fontes' First Confession is one of the exceptions in which childhood and children's voices are portrayed in a novel, a thematic analysis of the novel demonstrates that many of the most recurrent themes of the female novel are present in this story.
\end{abstract}

\section{A ChicANo ChILdHOOd EXPERIENCE}

The Literature written by the Chicanos after the decade of the 60s is, as Francisco Lomelí and Julio A. Martínez point out (1985: xi), "the Literature written since 1848 by Americans of Mexican descent or by Mexicans in the United States who write about the Mexican-American experience". This Mexican-American experience after the signing of the Treaty of Guadalupe Hidalgo in 1848 is, on the other hand, one of marked 
discrimination and rejection by the mainstream, anglo-dominant society. Occupying the lowest positions in the value system of the American social scale, the MexicanAmerican is a hard-working citizen, who, nevertheless, is looked down on. Moreover, he is incapable of clarifying and demystifying the stereotypes that describe him as a lazy "alien". As a consequence, the struggle of the first Mexican-American is aimed at the quest for recognition and acceptance as a fully-fledged member of society.

The decade of the $60 \mathrm{~s}$, a time of radical changes, gave rise to the first rebellious consciousness-raising movements, which paved the way for the creation and organization of what has been called the "Chicano Movement". The Chicano, thus, became a political activist who was eager to break down the ideological and social barriers that had enslaved him throughout the ages. Amongst other devices, this community found in Literature an extraordinarily valid mouthpiece for spreading the ideas and new values of the emerging Chicano, and concomitantly, for denouncing and revising the aforementioned discriminatory ones.

The novel represents one of the best channels for transmitting these ideas as well as the expectations of the Chicano community, for it clearly portrays the different situations its members live in, and provides its readers with the necessary impetus for their personal awakening and subsequent joining of the Movement. It is a novel of becoming which deals mainly with the process of consciousness-raising that its protagonists go through, and thus becomes the chronicle of the reconstruction of a fragmented and colonized identity. Themes such as the social and economical conditions of the members of the Chicano community, schooling and housing, the situation of the Chicanos in the fields, portrayals of the first organized political movements, family and domestic relationships etc. are largely in evidence in the Chicano Literature written throughout this period. The majority of the first Chicano novels are therefore, in general terms, adult "socio-political" novels (novels that show the tendency to portray the social and political plight of the Chicanos among its most recurrent themes). Given that the first steps towards the demands for the rights of the community were taken by male adults, one may assume that the presence of children or childhood as the central theme of a story is scarcely found in these first novels. As Martínez and Lomelí (1985:111) point out,

In the past the Chicano child has had little interest in literature because its irrelevancy to his or her existence. Today, the Chicano child is more likely to relate to what is read, for the literature has a more acceptable depiction of the Chicano.

Nevertheless, some of the first Chicano novels, and probably some of the most influential ones at that time, such as Jose Antonio Villarreal's Pocho (1959), a work of fiction that deals with the conflict that Richard, the protagonist, a young pocho, experiences between the traditions of his family and community and the new ways of life 
and behaviour he is just discovering, Rudolfo Anaya's Bless Me, Última (1972), the story or Tony, a young boy, who seeks for healing and guidance in Última, the curandera of the community, and Tomás Rivera's ...y no se lo tragó la tierra (1971), a collection of stories, whose main protagonist is also a young boy, which portray the situation of Mexican-American migrant workers, present young boys/adolescents as their main protagonists and expose the harsh reality of the Mexican-American experience of their times. However, whenever children who do not have the role of the protagonist of the story are portrayed in the novels written by Chicanos, they are generally depicted as passive members, like their mothers, of the family unit, stronghold of the community. Children are regarded as the outcome of the natural flow of life, the product of the widespread Christian belief that accounts for the fact that the role of the woman within the community is that of bringing up and rearing children. Therefore, the children portrayed in these novels are neither important nor decision-making-provoking characters.

This tendency changes drastically when the Chicanas force their way towards the dismantling of the patriarchal hierarchy, which they consider oppressive and constraining. Never having been considered fully-fledged members of their own community, but passive tradition-bearers and nourishers, the Chicanas opt to free from these chains, and, in the same way that in the case of their male counterparts, to reconstruct their colonized identity. As Tey Diana Rebolledo (1995: 97) explains in the following words, both the Chicana woman and the writer in particular, try to contribute to the writing of the story of their community, which had so far silenced and muted them:

However, when early Chicana writers began to try to define their identities form their own perspectives on the social and political situation, it was a struggle to define themselves both as women and as members of a ethnic group. Because theirs was a subjugated or subordinated discourse, they were trying to "inscribe" themselves in a collective and historical process that had discounted and silenced them.

Describing their situation of colonization as a three-pointed one, the Chicana finds the strong moral and religious values obsolete and considers them to impose a tradition that oppresses her. The idea of motherhood is thus depicted as the result of the dispossession by the woman of her own body, which consequently becomes a reproductive tool, controlled by male Chicanos. Nonetheless, these important efforts towards the appropriation and regaining of the female colonized body, result in the concept of motherhood as the most rewarding and self-defining processes a woman may endure. Understood as a spiritual gift exclusive to women, motherhood becomes the uppermost fulfilment of a woman's self. Furthermore, this regaining of the ability to be mothers, directly links them to their ancestors and becomes the nexus of union between 
the contemporary Chicanas and their more spiritual traditions, for as Ana Castillo (1995: 13) points out, "Woman's ability to give birth to a human being was acknowledged as sacred in the earliest traces of human history".

What is more, for the new Chicana woman, the capacity to bear children and raise them symbolizes the complete liberation of her body from the moral and social restrictions it had been subjected to since time immemorial. The stereotype of the woman as a passive mother is altered and develops into a more active, self-conscious one. Nevertheless, even though children acquire a great importance in the lives of the Chicana protagonists of many novels, we very rarely find stories whose main protagonists are children. In general terms, the Chicana novel, as Annie O. Eysturoy (1996: 3) describes, is a novel of becoming that chronicles the struggle for the creation of the identity of its protagonists.

This process of becoming, whether it is that of the child and adolescent or the somewhat older woman, is a recurrent theme in Chicana Literature, and due to this very subject matter, many Chicana narratives belong to the Bildungsroman genre, the literary form traditionally used to portray the process of self-development.

The figure of a Chicano/a adolescent, examples of which are found in Sandra Cisneros's The House on Mango Street (1989) or Denise Chavez's The Last of the Menu Girls (1987) etc, is more common than the one of the Chicano child in general terms. Monserrat Fontes's First Confession, stands out as one of the few novels written by Chicana authors whose protagonists are two children. On the basis of the importance of a thematic approach to establish analogies and/or divergences among different works, posited by Menachen Brinker amongst other critics, the aim of this essay is to discover the way in which several recurrent themes found in the body of Chicana Literature, in which the main protagonists are adult women or adolescents, are also present in Fontes' work, a story that at a first glance, could be depicted as a story of two children and of the account of the "infantile" problems they go through.

Theme's most common function for critics is the aid it affords in the description and interpretation of a work or group of works. Accordingly, changes tend to occur in degree of generality vs. particularity or of abstractness vs. concreteness as scrutiny shifts from the individual work to a group of works (...), to the whole corpus of an author's work, to the work a literary group, generation, or school (Brinker 1993: 22).

First Confession is the story of two kids, Andrea and Victor, who are members of a high class Mexican family. Like several other works written by Chicanas, it is a story of becoming, of the process of an identity that needs to be reconstructed. The easy and 
comfortable existence of the two children at the outcome of the novel, develops into a complex inner contradiction, in which their passage into the adult, morally correct world becomes the catalyst of the fragmentation of their naïve, controlled, past experience. Gloria Anzaldúa's notion of the dual identity of the Chicana woman, together with the idea of her existence in the limit, in the border of two worlds, is present throughout the novel, and becomes materialized in the personae of the two children. They hence become representative of the child/adult transit, of the enormous border existing between the controlled, organized, thus accepted "mainstream" society, and the disorganized, feared "other" society that they encounter outside the walls of their domestic environment.

Andrea and Victor's existence, parallel to that of the Chicanas, is one of constraint within the confines of their house, understood by their family as the only secure space for the children to be kept away from the influences of the outer, dangerous world. Nonetheless, this accommodation in the feminine, domestic environment produces a sense of anxiety in the two children, and more concretely in Andrea, who feels marginalized from the real life and understands her reality as one of enclosure and limitation. This experience recalls Leela Gandhi's (1998: 84) idea that accounts for the fact that "The "third-world-woman" is arguably housed in an "identifiable margin", a margin that becomes obviously unsatisfactory". Furthermore, the strong Christian values that they are acquiring at the time the story is taking place, for they are preparing for their First Communion, are also envisaged as non-consistent with the reality of the life that they are discovering beyond the frontiers of their house and their high-class, domestic existence, and thus becomes a symbol of their border existence.

Andrea's natural, domestic environment is one of women, even though her cousin Victor becomes her best companion during the summer holidays chronicled in the novel. The influence these women exert upon Andrea is extremely important, and is explicitly described as such in the second part of the novel, when the protagonist is portrayed as a young woman, and recalls her adventures and experiences throughout the summer of her First Communion. She says:

We were all girls.

These women had once been my size. There was Armida with her dress up behind the curtain, Candelaria with her pipe and her dead kids, Mother waiting for Father and Petra who seemed no other functioning life but to care for us (Fontes 1991: 129).

As may be inferred from the words above, each of the women who surrounded her was instrumental for the delineation of her identity, which began to emerge at that moment of her childhood. In a remarkable way, the vast majority of them symbolize the 
"traditional" woman, representing diverse manifestations of the role ascribed to women, and described by Mae Henderson (1995: 34) in the following terms: "women are supposed to live stably and provide stability for others". Her mother is the portrayal of the faithful and submissive mother and wife, who lives enclosed within the walls of her house. She clearly represents Alfredo Mirandé's (1979: 166) idea of the image of women in Chicano Literature, who are "universally warm, enduring, and uncomplaining". Candelaria, on the other hand, is the wise woman, the curandera, respected by everyone in the house. Petra, on the contrary, represents the woman who is always keen to help all the components of the family. She fulfils the characteristic role of the mother, for Andrea's family, having a comfortable economic situation, hire somebody to carry out the task traditionally linked to the mother.

Nonetheless, despite the fact that all these traditional women represent different images of the roles imposed upon women, they are all treated in a loving and respectful way by the writer. Notwithstanding, Andrea envisages a diametrically opposed type of woman as the model for the creation of her identity, her North American, Anglo grandmother, Paulette. She symbolizes the independent and free woman who voluntarily decides upon her life and breaks with the traditional Mexican vision of the feminine role. Andrea regards her as the mirror she wants to see herself in, as inferred from the following words:

I looked at Cristina and Reymundo and said, "Someday, I'll be her Paulette". Only Petra and Mother seemed slightly amused by my announcement. (Fontes 1991: 303)

She represents the feminist woman of the decades of the $60 \mathrm{~s}$ and $70 \mathrm{~s}$, and is described in direct contrast to the rest of the women in the story, who are the silent, submissive women of the Chicano community. Andrea's admiration for her grandmother, symbol of the white American society, together with her enforced accommodation in the traditional atmosphere which the feminine domestic environment represents, creates another important contradiction in the girl, whose existence becomes fragmented and divided, reinforcing the idea of her border existence. Notwithstanding, in an extremely (r)evolutionary way, she chooses to adopt and assimilate her dual existence and construct her identity on the basis of her ambivalent personality. This positive approach to the "marginalized", border position in which she lives, accounts for the idea of the constant reinvention and development of the individual identities of the members of "other" communities who experience continuous developing processes of socialization (Sollors 1989).

The idea of silence as one of the most repressing constraints that keeps the Chicana identity from developing, is also one of the aspects that directly links the story to the rest 
of the body of Literature produced by Chicana writers, and in this particular case, it becomes the core of the novel. The story of the Chicana woman has been one of imposed silence and muteness. Never allowed to express herself in a free way, the language of the woman, is also a colonized one. On the one hand, since it is a male-constructed and male-oriented kind of language, and on the other hand, because she is not authorized to use it in a free way, in order to generate her own, individual identity. As the feminist critic Elaine Showalter (1986: 255) explains,

The problem is not that language is insufficient to express women's consciousness but that women have been denied the full resources of language and have been forced into silence, euphemism, or circumlocution.

Furthermore, and directly connected to this idea of silence, the concept of the colonized, and therefore, non-existent feminine sexuality is deeply rooted in the traditional patriarchal community. Thus, the good woman is symbolized by a silent, submissive, childbearing woman, whose role in life is to perpetuate her community. These two concepts, which at a glance seem to be directly related to adulthood, are on the contrary, found in the story of our two kids. Their story takes place in a little town in Mexico, where the kids live an apparently easy, comfortable life. The reason for Victor's visit to his cousin is to spend his vacation with her, and at the same time, to prepare himself for his First Communion, a ritual that becomes the central axis that the plot of the novel revolves around. Religion, understood as one of the most important institutions within the Chicano community, is therefore, the catalyst behind the story of the kids, as well as Fontes's criticism. In Ana Castillo's (1995:11) words,

At this point in our this twenty plus years of Chicana conscientización and activism, women have begun and ardent investigation in many ways our spirituality and sexuality have been denied us by male legislature and religion.

The novel, thus, chronicles the painful dichotomy and the uneasiness that it exists between the need to transmit what life outside the sheltered walls of the house has taught them and the imposed silence that they have assimilated in their preparatory classes before their communion, which must only be broken when the ritual of the First Confession is celebrated. Drawing an analogy between the situation of the Chicanas and the one of the two children, Fontes strongly criticizes this imposed silence. In the case of the Chicanas, this muteness has contributed to the existence of strong fears and frontiers which are problematical for the development of their individual identity, for as Cherríe Moraga (1981: 30) posits,

How have I internalised my own oppression? How have I oppressed? Instead, we have let rhetoric do the job of poetry. Even the word "oppression" has lost its 
power. We need a new language, better words that can more closely describe women's fear of and resistance to one another; words that will not always come out sounding like dogma.

The strong sense of responsibility and the step towards an adult Christian life that the First Communion represents clashes directly with the discovery of sex by the two children. As in the case of the Chicana community in general, the important moral values the Chicano community relies on describe the idea of sexuality as something dirty and sinful for the two kids. Nevertheless, this revelation represents for them at the same time, a complete breakthrough due to the concept of goodness and rightfulness. The idea of sex as something obscure that has to be done in the darkness is clearly represented by Armida, a woman who "gets money from letting herself being touched".

While they touched her she raised her head and smiled and we could see her front teeth, all of which were framed in gold. While the boys touched and squeezed, and tasted her breasts, she would flutter her fingers up and down the zipper of their pants" (Fontes 1991: 117)

The discovery of this unknown world, which is presented as extremely dirty and as a taboo, is of the utmost importance for the development of the story. Furthermore, the idea of silence which is so deeply rooted in the minds of the children, brings with it consequences that affect their development towards adulthood. The body and sexuality as something shameful and to be hidden, represented in Armida, creates a strong state of guilt in both of them. Speaking the body, thus, among other devices, becomes essential for the positive development of the woman's/children's identity, for up to that moment, as Ana Castillo (1995: 122) explains, "We maintained the business of our bodies behind closed doors. ... We had been taught not to name those feelings and fantasies, much less affirm their meanings".

Notwithstanding, as the novel portrays, whenever the body preserves its negative connotations, it becomes the jail in which the identity is trapped and subjugated. In the case of Victor, the fact of growing up denying his homosexuality (a fact that will be discovered in the last pages of the novel), leads him to the uppermost rejection of his existence, by means of committing suicide. Trapped in his self-imposed silence, he does not feel strong enough to bear the denial of his existence within his own community. On the contrary, the novel portrays the importance of speaking, whenever it implies a conscious, personal movement towards the emergence from the "underworld". The power of the use of words and speaking out about one's own feelings and ideas have to be accompanied with a desire to do so. In the case of the First Communion, it is a powerful institution that manipulates and colonizes the children's ability to speak. Fontes strongly criticizes this type of colonization, which evokes the patriarchal 
tendency to decide for the rest of the members of the community. These imposed words are not valid for the definition of the children's identity, and become a dangerous weapon against themselves, creating a strong sense of culpability in them. Pushed by the obligation to speak they confess the fact that they have seen Armida sell her body. Consequently, she commits suicide, terrified by the violence of his husband's reaction.

The novel is therefore a harsh criticism of the power exerted by traditional religious institutions over children, who in this case, may well symbolize the innocent/naïve woman who lacks language and knowledge, and has to be instructed in the laws of moral rightfulness. These laws, nevertheless, become repressive and diminish the capacity of the "inferior being" (children/women) to create and shape his own identity. Therefore, the dichotomy between the need to speak freely and the imposed moment to speak, ends up in a negative and painful way. On the contrary, the free, voluntary act of giving words to one's innermost desires, is presented as extremely healing and positive. In contrast to Victor, the depiction of Andrea in her adulthood, as a singer who uses her words to denounce and vindicate what she thinks should be changed, symbolizes the importance of the individual use of one's own language.

In conclusion, it could be stated that Fontes's novel, though one of only a handful which deal with childhood as the main subject, can indeed be considered a novel that follows the tendency drawn by Chicana writers in the last decades, for as Tey Diana Rebolledo (1995: 107-108) explains, "As Chicana writers "remember" their childhood, they are witnesses to the construction of their own identities and the development of an understanding of their historical role in their families and communities". Consequently, some of the most recurrent themes found in the literary production of contemporary Chicana authors, such as the relationship among women, the house and the family as a symbol of constraint and enclosure, the need to break an imposed and painful silence and the discovery of sexuality as a turning point in the process of delineation of the decolonised Chicana identity, are clearly found in the novel, for as Steven Hannabus(1986: 103) posits when theorizing about the idea of presenting children as protagonists of "adult" novels,

Often, such works are not for children: they simple use them as narrative devices or convenient mediums to gain access to hidden and over-covered dimensions of memory and sensation.

The utilization of the novel as one of the main devices to denounce the situation of Chicanas and propose solutions is clearly reflected in First Confession, which becomes a fierce criticism of the religious, personal and linguistic colonization. Childhood is thus presented as a parallel to the situation of the Chicana. Both communities having been considered naïve, submissive and dependent on the adult male figure, become the targets 
of its colonization. The adult male Chicano community, turns its wrath, provoked by the mainstream society, towards children and women, thus reproducing the discriminatory devices exerted upon it. Fontes's novel, together with many other Chicana novels, calls for the decolonisation of the children and women's selves, as well as for the revision and redescription of many of the restrictive traditions which the Chicano community relies on.

\section{REFERENCES}

Anzaldúa, G. 1987. Borderlands. La Frontera. The New Mestiza. San Francisco: Aunt Lute Books.

Brinker, M. 1993. “Theme and Interpretation”. The Return of Thematic Criticism. Ed. W. Sollors. Cambridge, MA: Harvard University Press. 21-37.

Castillo, A. 1995. Massacre of the Dreamers. Essays of Xicanisma. New York: Penguin Plume Books.

Eysturoy, A.O. 1996. Daughters of Self-creation. The Contemporary Chicana Novel. Albuquerque: University of New Mexico Press.

Fontes, M. 1991. First Confession. New York: W.W. Norton \& Co.

Ghandi, L. 1998. Postcolonial Theory. A Critical Introduction. Edinburgh: Edinburgh University Press.

Hannabus, Stuart. 1986. “ The Child's Eye: A Literary Viewpoint”. International Review. Children's Literature and Librarianhsip. Vol. 1, no. 3, Winter 1986. 103-114.

Henderson, M., ed. 1995. Borders, Boundaries and Frames. Cultural Criticism and Cultural Studies. New York: Routledge.

Martínez, J. and Limelí, F., eds. 1985. Chicano Literature. A Reference Guide. Westport: Greenwood Press.

Mirandé, A. 1979. La Chicana. The Mexican-American Woman. Chicago: University of Chicago Press.

Moraga, C. and Anzaldúa, G., eds. 1981. This Bridge Called My Back. Writings by Radical Women of Color. New York: Kitchen Table Press.

Rebolledo, T. D. 1995. Women Singing in the Snow. A Cultural Analysis of Chicana Literature. Tucson: University of Arizona Press.

Showalter, E. 1986. The New Feminist Criticism. London:Virago.

Sollors, W. 1989. The Invention of Ethnicity. New York, Oxford: Oxford University Press. 